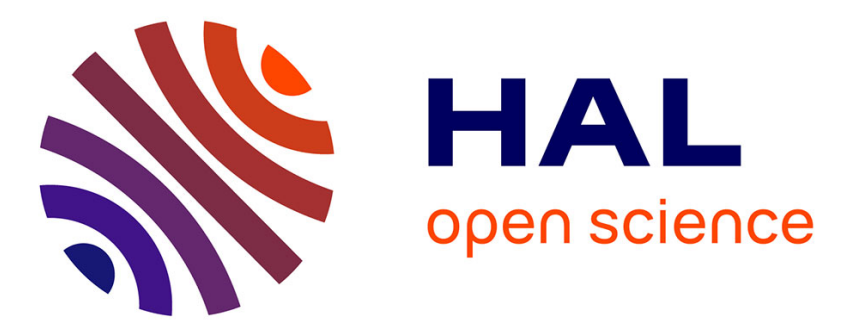

\title{
Carbon mineralization in soil of roots from twenty crop species, as affected by their chemical composition and botanical family
}

Marciel Redin, René Guénon, Sylvie Recous, Raquel Schmatz, Luana

Liberalesso de Freitas, Celso Aita, Sandro Jose Giacomini

\section{To cite this version:}

Marciel Redin, René Guénon, Sylvie Recous, Raquel Schmatz, Luana Liberalesso de Freitas, et al.. Carbon mineralization in soil of roots from twenty crop species, as affected by their chemical composition and botanical family. Plant and Soil, 2014, 378 (1-2), pp.205-214. 10.1007/s11104-013-2021-5 . hal-01268544

\section{HAL Id: hal-01268544 \\ https://hal.science/hal-01268544}

Submitted on 28 May 2020

HAL is a multi-disciplinary open access archive for the deposit and dissemination of scientific research documents, whether they are published or not. The documents may come from teaching and research institutions in France or abroad, or from public or private research centers.
L'archive ouverte pluridisciplinaire HAL, est destinée au dépôt et à la diffusion de documents scientifiques de niveau recherche, publiés ou non, émanant des établissements d'enseignement et de recherche français ou étrangers, des laboratoires publics ou privés. 


\title{
Carbon mineralization in soil of roots from twenty crop species, as affected by their chemical composition and botanical family
}

\author{
Marciel Redin ${ }^{1}$, René Guénon ${ }^{2,3}$, Sylvie Recous ${ }^{2,3}$, Raquel Schmatz ${ }^{1}$, Luana Liberalesso de Freitas ${ }^{1}$, \\ Celso Aita ${ }^{1}$, Sandro José Giacomini ${ }^{1}$
}

${ }^{1}$ Federal University of Santa Maria, Department of Soil Science, 97119-900 Santa Maria, RS, Brazil

${ }^{2}$ INRA, UMR614 Fractionnement des AgroRessources et Environnement, F-51000 Reims, France

${ }^{3}$ Université Reims-Champagne Ardenne, UMR614 Fractionnement des AgroRessources et Environnement, 51100 Reims, France

\begin{abstract}
Background and aims: Our objective was to relate chemical composition of roots of a wide range of annual crops to root decomposition, so as to assess roots potential contribution to soil carbon (C).

Methods: Roots from 20 different crops and 4 botanical families, collected under field conditions were incubated in soil for 120 days at $25^{\circ} \mathrm{C}$. The initial chemical composition of roots was determined. The $\mathrm{C}$ mineralization was assessed by the continuous measurement of $\mathrm{CO}_{2}$ release and using single exponential model. PCA analysis was used to explore qualitative pattern in root quality and decomposition.

Results: PCA analysis showed that chemical characteristics (traits) differentiated plant families. The mineralization of root $\mathrm{C}$ varied greatly in terms of kinetics and in the total amount of C mineralized (36\% to $59 \%$ of added C). Mineralization constant ( $k$ value) was negatively correlated with hemicelluloses and positively with $\mathrm{N}$ content. Poaceae roots that combined high hemicelluloses content, low cellulose and low total $\mathrm{N}$, showed low degradation rate and cumulative mineralization.

Conclusions: The chemical composition of roots, as for the above-ground parts of plants, can correctly predict their rate of decomposition in soils. The taxonomic affiliation enhances the understanding of the chemical determinants of quality of roots.
\end{abstract}

Keywords: carbon mineralization; chemical composition; decomposition rate; litter quality; root; trait

\section{Introduction}

The decomposition of plant residues is a key process in terrestrial agro-ecosystems. However the decomposition of plant residues has been much better studied for above-ground than for below-ground components (Zhang et al. 2008). Nonetheless, given the role of cropped soils in $\mathrm{C}$ sequestration, the dynamics of root decomposition and $\mathrm{C}$ stabilization in soil has become a major environmental challenge and received increasing attention during the last decade (Abiven et al. 2005, Rasse et al. 2005; Aulen et al. 2012). Within a given management system, many of the factors (e.g., climate and tillage) that influence SOC turnover will be similar. The quantity of residue returned to the soil influences the soil organic matter content, but quality differences among residues become important when other factors are held constant. According to many authors (Heal et al. 1997; Trinsoutrot et al. 2000; Bertrand et al. 2006), the prediction of $\mathrm{C}$ mineralization as a function of chemical quality is complex for plant tissues because of the numerous interactions between plant components (e.g., lignin, polysaccharides, polyphenols, and soluble fractions). Roots, which are rich in secondary cell walls, 
typically contain more lignified cells than aerial plant parts (De Neergaard et al. 2002; Bertrand et al. 2006; Carrera et al. 2008).

Because most studies investigating plant root decomposition have been restricted to a limited number of plant species and have utilized various incubation protocols (e.g., temperature, humidity, $\mathrm{N}$ available), it is difficult to establish a generic relationship between the chemical features of roots and $\mathrm{C}$ decomposition in soil for varied species. In natural ecosystems, it has been shown that root morphology and chemistry differ widely between species (Aulen et al. 2012; Piconcochard et al. 2012) and roots "traits values" are used to study interspecific variation in roots decomposition. For example, it was shown that Poaceae, with high cellulose concentration and low concentrations of soluble compounds decomposed more slowly than Asteraceae and Fabaceae (Birouste et al. 2012).

Therefore, the first objective of this study was to assess the chemical composition of roots in a large range of annual crop species and to investigate how their chemical composition affects their potential mineralization in soil. The second objective of this study was to examine whether the decomposition rates of roots of annual crops differ between taxonomic groups. In this study, we selected twenty crops from agricultural systems in Brazil with varied agronomic uses (main and cover crops) and in which we expected divergent chemical compositions. We compared the potential decomposition rates of roots - measured under standard conditions by controlling other parameters to avoid confounding effects (particularly the availability of inorganic soil N).We hypothesized that the botanical family of the different crops dictates their chemical features and has a significant impact on their decomposition in soil.

\section{Materials and methods}

Plant roots

Twenty representative species of plants (main crops and cover crops) of agricultural systems in Brazil were studied (Table 1). The plants selected included nine Poaceae (Gramineae), eight Fabaceae (legumes), two Brassicaceae, and one Asteraceae. The plants were cultivated during the autumn/winter (9 species) and spring/summer (11 species) in a Typic Hapludalf soil under a no-till system in the experimental area of the Soil Department $\left(29^{\circ} 41^{\prime} \mathrm{S}, 53^{\circ} 48^{\prime} \mathrm{W}\right.$; approximately $90 \mathrm{~m}$ elevation) of the Federal University of Santa Maria in the state of Rio Grande do Sul, Brazil. The region has a subtropical climate, with a mean annual precipitation of $1,686 \mathrm{~mm}$ and a mean air temperature of $19.3^{\circ} \mathrm{C}$. For the previous 12 years, the experimental site had been cultivated using a no-till system. All the crops were given appropriate management according to the technical recommendations for the area. The roots of the plants were collected using an excavation method at the flowering stage in the $0-10 \mathrm{~cm}$-layer of microplots (with areas of 0.09 to $0.36 \mathrm{~m}^{2}$, depending on the type of crop), with 3 field replicates. The sampling stage was chosen as the most representative time for the root system mass and composition at the start of senescence during the growing season (e.g., Amos and Walters 2006).

The roots were manually separated from the soil under running water over a sieve with 1-mm-diameter openings; the nodules were removed for the Fabaceae species plants, and the roots were dried at $40^{\circ} \mathrm{C}$. The roots were separated by diameter $(\varnothing)$ into coarse $(\varnothing \geq 2$ $\mathrm{mm})$ and fine $(1<\varnothing<2 \mathrm{~mm})$ fractions to determine the proportions of these fractions for each plant species (Table 1). Coarse roots were cut into pieces approximately $0.3 \mathrm{~cm}$ thick. All the roots (fine) and root pieces (coarse) were then cut into pieces $1 \mathrm{~cm}$ in length for incubation. A sub-sample of each type of root was also dried at $65^{\circ} \mathrm{C}$ and finely ground $(<1$ $\mathrm{mm}$ ) for the chemical analyses. 


\section{Final version of manuscript published in: Plant and Soil , 2014, DOI 10.1007/s11104-013-2021-5}

Table 1: List of the sampled main crops and cover crops and initial proportion of coarse and fine roots.

\begin{tabular}{|c|c|c|c|c|c|c|}
\hline Helianthus annuus & Sunflower & Asteraceae & Main crop & $69 \pm 9.6$ & $31 \pm 5.8$ & $\overline{4}$ \\
\hline Raphanus sativus oleiferus & Oilseed radish & Brassicaceae & Cover crop & $89 \pm 4.2$ & $11 \pm 7.1$ & 14 \\
\hline Phaseolus vulgaris & Bean & Fabaceae & Main crop & $59 \pm 8.5$ & $41 \pm 5.3$ & 1 \\
\hline Glycine $\max$ & Soybean & Fabaceae & Main crop & $55 \pm 5.7$ & $45 \pm 3.7$ & 2 \\
\hline Crotalaria juncea & Sunn hemp & Fabaceae & Cover crop & $74 \pm 4.2$ & $26 \pm 4.3$ & 5 \\
\hline Crotalaria spectabilis & Showy rattlebox & Fabaceae & Cover crop & $96 \pm 4.1$ & $4 \pm 3.9$ & 10 \\
\hline Vicia sativa & Vetch & Fabaceae & Cover crop & $0 \pm 0.0$ & $100 \pm 0.0$ & 12 \\
\hline Pisum arvense & Pea & Fabaceae & Cover crop & $0 \pm 0.0$ & $100 \pm 0.0$ & 16 \\
\hline Zea mays & Maize & Poaceae & Main crop & $48 \pm 2.1$ & $52 \pm 4.6$ & 3 \\
\hline Pennisetum glaucum & Millet & Poaceae & Cover crop & $27 \pm 2.7$ & $73 \pm 3.6$ & 8 \\
\hline Sorghum bicolor & Sorghum & Poaceae & Main crop & $58 \pm 4.4$ & $42 \pm 4.1$ & 9 \\
\hline Hordeum vulgare & Barley & Poaceae & Main crop & $0 \pm 0.0$ & $100 \pm 0.0$ & 19 \\
\hline Lolium multiflorum & Ryegrass & Poaceae & Cover crop & $0 \pm 0.0$ & $100 \pm 0.0$ & 20 \\
\hline
\end{tabular}

${ }^{\mathrm{a}}$ Diameter of roots $(\varnothing)$ : coarse $=\varnothing \geq 2 \mathrm{~mm}$ and fine $=1<\varnothing<2 \mathrm{~mm}$. Means $(n=3) \pm$ standard deviation (S.D).

${ }^{\mathrm{b}}$ Reference 
Chemical analyses

The total organic carbon (C) and total $\mathrm{N}(\mathrm{N})$ contents of the roots were determined from finely ground sub-samples dried at $65^{\circ} \mathrm{C}$ using an elemental autoanalyzer (FlashEA 1112, Thermo Finnigan, Milan, Italy). A proximate analysis using the Van Soest method was performed using sub-samples of ground roots pre-dried at $40^{\circ} \mathrm{C}$. The soluble (SOL), cellulose (CEL), hemicellulose (HEM), and lignin (LIG) fractions of the roots were determined by proximate analysis (Van Soest 1963). Neutral digestion was performed with $0.3 \mathrm{~g}$ of roots and $30 \mathrm{ml}$ of neutral detergent solution. For acid digestion, $0.6 \mathrm{~g}$ of roots and $60 \mathrm{ml}$ of detergent solution acid were used. The digestions were performed by boiling the material in the digester block at $150^{\circ} \mathrm{C}$ for 1 hour. After digestion, the samples were filtered by vacuum suction using a filter crucible and then washed with hot distilled water $\left(90^{\circ} \mathrm{C}\right)$ and acetone $(30-40 \mathrm{ml})$. The fibers were dried at $105^{\circ} \mathrm{C}$ for 12 hours. The SOL content was determined from the difference in the weight before and after neutral digestion. The HEM content was determined from the difference between the percentage of total neutral fiber and the percentage of acid detergent fiber. The CEL content of the acid fiber was obtained after digestion with $12 \mathrm{M} \mathrm{H}_{2} \mathrm{SO}_{4}$ for 3 hours; the material remaining after quantification of the CEL content was burned in a muffle furnace at $500^{\circ} \mathrm{C}$ for 3 hours to determine the LIG content. The water-soluble organic carbon (Csw), and water-soluble total nitrogen (Nsw) was extracted using $0.5 \mathrm{~g}$ of finely ground roots pre-dried at $40^{\circ} \mathrm{C}$. The roots were placed in a 60-ml snap cap with distilled water $\left(20^{\circ} \mathrm{C}\right)$ and mechanically stirred for 30 minutes. After mixing, the material was filtered (Whatman $\mathrm{n}^{\circ} 5$ ), and the contents of Csw and Nsw in the filtrate were determined by expressing at $65^{\circ} \mathrm{C}$. The quantification of soluble polyphenols (POL) was made with $0.75 \mathrm{~g}$ of finely ground roots pre-dried at $40^{\circ} \mathrm{C}$. POL extraction was made with aqueous methanol $(1: 1)$ in a water bath at $80^{\circ} \mathrm{C}$ for 1 hour (Tian et al. 1995). After extraction, the aqueous solution was filtered (Whatman $n^{\circ} 2$ ). After addition of the Follin-Denis reagent, POL content was determined by colorimetry (absorbance 760nm) (King and Health 1967). All the analyses were performed with three replicates and the results are shown in Table 2.

Soil, treatments, and experimental conditions

The soil used in the incubation experiment was a Typic Hapludalf (USDA classification) collected from the $0-10-\mathrm{cm}$ layer in the same area as the plants. This soil contains $120 \mathrm{~g} \mathrm{~kg}^{-1}$ clay, $280 \mathrm{~g} \mathrm{~kg}^{-1}$ silt, $600 \mathrm{~g} \mathrm{~kg}^{-1}$ sand, $8.7 \mathrm{~g} \mathrm{~kg}^{-1}$ organic $\mathrm{C}$, and $0.9 \mathrm{~g} \mathrm{~kg}^{-1}$ total $\mathrm{N}$ and has a $\mathrm{pH}$ (soil $\mathrm{H}_{2} \mathrm{O}$ ) of 5.4. Fresh soil samples were sieved to $4 \mathrm{~mm}$ and then cleaned manually to remove the visible crop residues. Potassium nitrate $\left(\mathrm{KNO}_{3}\right)$ was added to obtain a final concentration of $77 \mathrm{mg} \mathrm{N} \mathrm{kg}{ }^{-1}$ of soil to prevent limited decomposition due to $\mathrm{N}$ availability (Recous et al. 1995). The concentration of the added $\mathrm{N}$ solution was calculated to achieve a soil moisture content of $80 \%$ of field capacity. The soil was preincubated in plastic bags at $25^{\circ} \mathrm{C}$ for 5 days.

The experiment consisted of an incubation conducted for 120 days in the dark at $25 \pm 1{ }^{\circ} \mathrm{C}$ to measure $\mathrm{C}$ mineralization of the roots. The 21 treatments consisted of a non-amended soil (as a control) and soil + roots for the 20 plant species listed in Table 1. The treatments were arranged as a completely randomized design, and each treatment was replicated three times. For each replicate, a sub-sample of $134 \mathrm{~g}$ soil at $13.8 \%$ moisture (equivalent to $80 \%$ of field capacity) was obtained, to which particles of root were added at the rate of $2.5 \mathrm{~g}$ DM per $\mathrm{kg}$ of dry soil (equal to an incorporation rate of 1.53 $\left.\mathrm{Mg} \mathrm{DM} \mathrm{ha}{ }^{-1}\right)$. This was equivalent to the addition of 874 (wheat) to 1085 (soybean) $\mathrm{mg}$ $\mathrm{C} \mathrm{kg}^{-1}$ of dry soil and 12 (sunflower) to 86 (vetch) $\mathrm{mg} \mathrm{N} \mathrm{kg}^{-1}$ of dry soil. First, for each replicate, a sub-sample of $67 \mathrm{~g}$ moist soil + root particles was placed in a 110-ml 
cylindrical acrylic pot $(5.0 \mathrm{~cm}$ in diameter and $5.0 \mathrm{~cm}$ in height) and compressed to a height soil + roots particles was placed in the same acrylic pot and compressed to a total height of $5 \mathrm{~cm}$. Thus, the soil in each pot reached a final bulk density of $1.2 \mathrm{~g} \mathrm{~cm}^{-3}$. Each acrylic pot was placed in a 1000-ml glass jar prior to incubation.

\section{Analytical procedures}

$\mathrm{C}$ mineralization of the roots was assessed by quantifying $\mathrm{CO}_{2}$ release. The $\mathrm{CO}_{2}$ produced in the soil was trapped in $10 \mathrm{ml}$ of $1 \mathrm{M} \mathrm{NaOH}$ in a beaker placed inside each glass jar. The carbonate trapped in the $\mathrm{NaOH}$ was precipitated with a $\mathrm{BaCl}_{2}$ solution in excess of $2 \mathrm{M}$, and the remaining $\mathrm{NaOH}$ was titrated with $1 \mathrm{M} \mathrm{HCl}$. Titrations were performed at 2, 4, 7, $10,14,21,28,35,50,70,90$, and 120 days and the $\mathrm{NaOH}$ beakers were changed at each sampling time. At all sampling times, the jars were aerated for 10 minutes to renew the internal atmosphere, and the soil water content was checked by weighing and was adjusted as necessary. The apparent $\mathrm{C}$ mineralization of the roots was calculated by subtracting the amounts of $\mathrm{CO}_{2}-\mathrm{C}$ evolved from the control treatment from the amounts of $\mathrm{CO}_{2}-\mathrm{C}$ evolved from the amended treatments. Apparent mineralization assumes that there is no effect of root addition on soil $\mathrm{C}$ mineralization (no priming effect) or that this effect is similar, regardless of the type of roots added.

Data and statistical analyses

Data of kinetics of mineralization and of cumulative mineralized $\mathrm{C}$ measured over 120 days were analyzed by one-way analysis of variance. Least significant difference tests $(P<0.05)$ were used to determine where significant differences occurred. All data were analyzed using STATISTICA ${ }^{\circledR}$ statistical software (version 7.0).

To get a quantitative measure of the relative importance of the initial chemical characteristics of roots in determining root mineralization, we first calculated $\mathrm{C}$ mineralization using an exponential equation, according to Jung et al. (2011):

Cmin $=C_{0}\left(1-\mathrm{e}^{-k \text { day }}\right)$

with $\mathrm{Cmin}$ is the amount of mineralized carbon, $C_{0}$ is a potentially mineralizable $\mathrm{C}$ pool, $\mathrm{k}$ is a mineralization constant, and day is the incubation period.

Stepwise multiple regression analysis was then used to determine which combinations of chemical variables best explained the variations in $C 0$ and $k$. Only those variables that were found to be significant at $P<0.05$ were retained in the regressions. Regressions were performed with all available chemical variables and with the variables obtained by Van Soest analysis, only.

A principal component analysis (PCA) was performed to address the question of what are the chemical traits that differentiate plant families, according to Aulen et al. (2012). PCA was done on the correlation matrix obtained from the results of the proximate analysis (i.e., SOL, CEL, HEM, and LIG), C, N, watersoluble fractions (i.e., $\mathrm{Csw}$, and $\mathrm{Nsw}$ ) and POL. The potentially mineralizable $\mathrm{C}$ pool $\left(C_{0}\right)$, and the mineralization constant $(k)$ were added as supplementary variables (i.e., not included in the ordination of species) to analyze relationships with chemical characteristics. The PCA produced an ordination of the species and the chemical composition of the roots, which were plotted in one and two dimensions, respectively, based on the scores of the first two principal components (PCs). A correlation circle was computed to assess the importance of each chemical component in the PC axes. We considered $r$ values (i.e., correlation coefficient) as significant contributor when $r \geq 0.5$ (e.g., Guénon et al. 2011). 


\section{Final version of manuscript published in: Plant and Soil , 2014, DOI 10.1007/s11104-013-2021-5}

Table 2: Initial composition of the roots $\left(\mathrm{g} \mathrm{kg}^{-1} \mathrm{DM}\right)$ : Van Soest fractions, total $\mathrm{C}$ and $\mathrm{N}$, water-soluble $\mathrm{C}$ and $\mathrm{N}$, and polyphenols content.

\begin{tabular}{|c|c|c|c|c|c|c|c|c|c|}
\hline Plant (REF) & $\mathrm{SOL}^{\mathrm{a}}$ & HEM & CEL & LIG & $\mathrm{C}$ & $\mathrm{N}$ & $\mathrm{Csw}$ & Nsw & POL \\
\hline Sunflower (4) & $192 \pm 3.0$ & $153 \pm 8.9$ & $514 \pm 3.8$ & $140 \pm 6.2$ & $469 \pm 4.5$ & $5.2 \pm 0.1$ & $71 \pm 6.7$ & $1.9 \pm 0.5$ & $9.6 \pm 0.7$ \\
\hline Oilseed radish (14) & $328 \pm 6.5$ & $144 \pm 5.9$ & $402 \pm 7.4$ & $126 \pm 2.6$ & $462 \pm 3.6$ & $11.4 \pm 0.1$ & $80 \pm 6.0$ & $6.8 \pm 1.0$ & $5.7 \pm 0.4$ \\
\hline Oilseed rape (18) & $258 \pm 8.1$ & $191 \pm 8.5$ & $409 \pm 2.3$ & $142 \pm 4.9$ & $452 \pm 4.9$ & $6.2 \pm 0.8$ & $81 \pm 8.4$ & $4.3 \pm 0.4$ & $3.7 \pm 0.1$ \\
\hline Soybean (2) & $162 \pm 7.3$ & $181 \pm 8.9$ & $469 \pm 2.4$ & $188 \pm 6.5$ & $462 \pm 3.2$ & $14.6 \pm 0.6$ & $50 \pm 2.2$ & $7.5 \pm 0.3$ & $7.0 \pm 0.4$ \\
\hline Sunn hemp (5) & $168 \pm 1.7$ & $200 \pm 8.1$ & $517 \pm 9.5$ & $116 \pm 4.5$ & $463 \pm 2.1$ & $10.6 \pm 0.3$ & $69 \pm 3.4$ & $2.4 \pm 0.1$ & $5.2 \pm 0.2$ \\
\hline Jack bean (6) & $221 \pm 2.5$ & $190 \pm 7.3$ & $476 \pm 1.6$ & $112 \pm 8.9$ & $459 \pm 3.0$ & $13.6 \pm 0.4$ & $73 \pm 2.3$ & $3.6 \pm 0.1$ & $4.1 \pm 0.1$ \\
\hline Vetch (12) & $393 \pm 3.4$ & $136 \pm 1.6$ & $276 \pm 3.0$ & $127 \pm 3.7$ & $469 \pm 9.2$ & $37.9 \pm 0.9$ & $115 \pm 14.2$ & $18.7 \pm 1.3$ & $24.8 \pm 1.2$ \\
\hline Pea (16) & $414 \pm 7.8$ & $202 \pm 2.4$ & $279 \pm 5.2$ & $105 \pm 4.4$ & $464 \pm 9.7$ & $37.3 \pm 1.8$ & $113 \pm 11.8$ & $26.1 \pm 2.9$ & $39.5 \pm 0.9$ \\
\hline Maize (3) & $256 \pm 2.4$ & $318 \pm 2.6$ & $355 \pm 8.8$ & $71 \pm 7.6$ & $481 \pm 4.8$ & $13.9 \pm 0.3$ & $83 \pm 5.6$ & $10.2 \pm 0.8$ & $7.9 \pm 0.3$ \\
\hline Millet (8) & $263 \pm 9.0$ & $153 \pm 4.5$ & $456 \pm 8.4$ & $127 \pm 3.7$ & $448 \pm 5.2$ & $11.4 \pm 0.4$ & $48 \pm 3.7$ & $1.0 \pm 0.1$ & $10.3 \pm 0.7$ \\
\hline Sorghum (9) & $302 \pm 9.9$ & $253 \pm 2.0$ & $357 \pm 4.1$ & $88 \pm 2.6$ & $464 \pm 3.8$ & $12.0 \pm 0.4$ & $72 \pm 3.5$ & $6.4 \pm 0.3$ & $17.5 \pm 0.3$ \\
\hline Black oat (11) & $200 \pm 2.8$ & $290 \pm 2.3$ & $437 \pm 4.2$ & $73 \pm 4.4$ & $461 \pm 9.7$ & $11.7 \pm 0.3$ & $57 \pm 4.5$ & $3.9 \pm 0.6$ & $5.4 \pm 0.3$ \\
\hline Ryegrass (20) & $223 \pm 9.0$ & $324 \pm 5.8$ & $391 \pm 4.4$ & $62 \pm 7.5$ & $458 \pm 9.6$ & $8.2 \pm 0.2$ & $54 \pm 3.1$ & $3.1 \pm 0.3$ & $8.4 \pm 0.2$ \\
\hline
\end{tabular}

${ }^{\text {a }}$ SOL: Soluble fraction (Van Soest); HEM: Hemicellulose; CEL: Cellulose; LIG: Lignin; C: Total carbon; N: Total nitrogen; Csw: Water-soluble carbon;

Nsw: Water-soluble nitrogen; POL: Soluble polyphenols. Means $(n=3) \pm$ standard deviation (S.D). 


\section{Results}

Chemical compositions of roots

The chemical compositions of the roots studied are summarized in Table 2 and were analyzed by a principal component analysis (PCA) to identify the most significant differences among the species (Fig. 1). The $\mathrm{C}$ contents ranged from $424 \mathrm{~g} \mathrm{~kg}^{-1}$ (rye) to $490 \mathrm{~g}$ $\mathrm{kg}^{-1}$ (barley), and the $\mathrm{N}$ contents ranged from $5.2 \mathrm{~g} \mathrm{~kg}^{-1}$ (sunflower) to $37.9 \mathrm{~g} \mathrm{~kg}^{-1}$ (vetch), resulting in $\mathrm{C} / \mathrm{N}$ ratios ranging from 12 to 90 (Table 2). The LIG contents of the roots ranged from $62 \mathrm{~g} \mathrm{~kg}^{-1}$ (ryegrass) to $188 \mathrm{~g} \mathrm{~kg}^{-1}$ (soybean) with, on average, lower LIG contents in the roots of Poaceae species plants than in the roots of plants from other families. The roots of dicotyledonous species (mainly Fabaceae) exhibited high variability in their chemical compositions, with, on average, higher SOL, CEL, LIG, and total $\mathrm{N}$ contents than the roots of the species from the Poaceae family. As a result, this latter group exhibited low variability in composition among different species and was characterized by higher HEM contents (Table 2).

PCA showed that the first two principal components (PC) accounted for $71 \%$ of the total variance of the data (Fig. 1). PC 1 explained $50 \%$ of the variance of the data and discriminated clearly the Fabaceae species with mucuna (7), vetch (12) and pea (16) in the negative part (Fig. 1a) significantly correlated with the soluble fractions (Van Soest and water-soluble), $\mathrm{POL}$ and total $\mathrm{N}$ contents (in the range $r=-0.91$ to -0.93 ) (Fig. 1b). Other Fabaceae, Asteraceae, and Brassicaceae species were in the positive part, and most strongly correlated with the CEL ( $r=0.73$ ) (Fig. $1 \mathrm{a}, \mathrm{b})$. PC 2 explained $21 \%$ of the variance of the data, and identified the Poaceae species mostly in the positive part of PCA (Fig. 1a), as significantly correlated with the HEM content $(r=0.91)$ (Fig. 1b). SOL, N, Csw, Nsw and POL appeared strongly correlated to each other which mainly reflects the chemical composition of the Fabaceae species 7, 12 and 16.
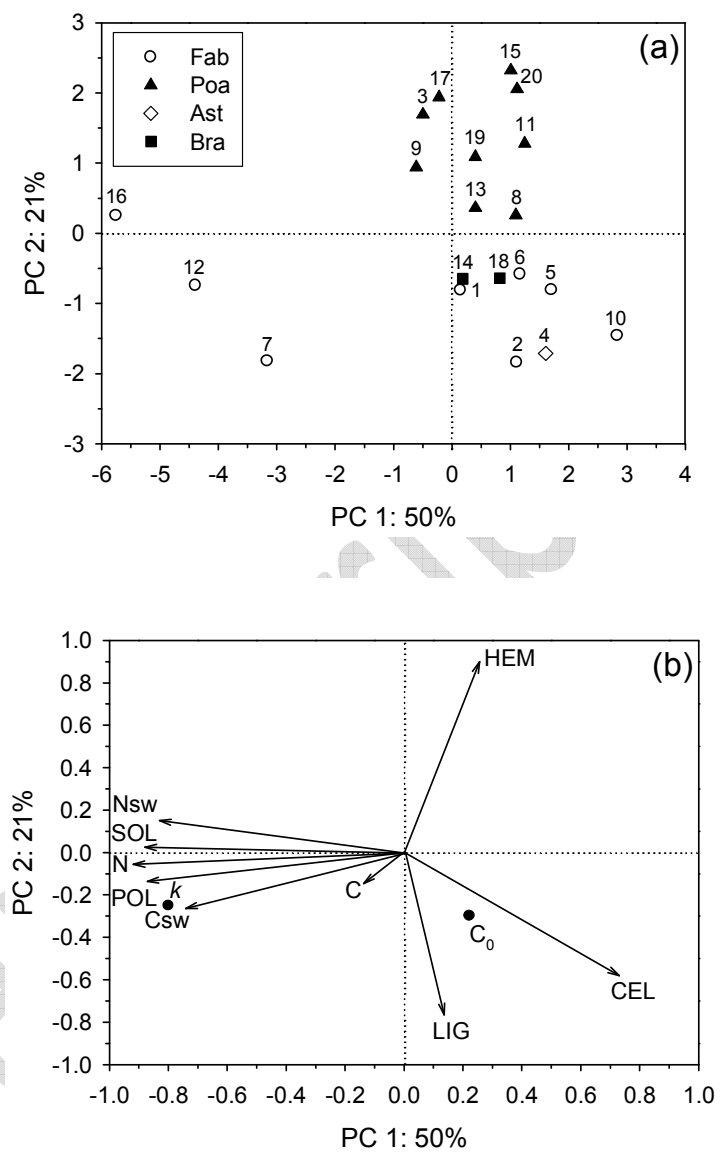

Fig. 1: Factorial map (PC 1 x PC 2) (a) and correlation circle (b) obtained from the principal component analysis (PCA) performed using the data for the chemical composition of 20 root species (i.e., Van Soest fractions, total $\mathrm{C}$, total $\mathrm{N}$, water-soluble fractions and polyphenols). Mineralization constant $(k)$ and mineralizable $\mathrm{C}$ pool $\left(C_{0}\right)$ were added as supplementary variables i.e., not included in the ordination of species. The species are identified according to the botanical family. Fab: Fabaceae; Poa: Poaceae; Ast: Asteraceae; Bra: Brassicaceae. The identification numbers of the 20 species studied are provided in Table 1 . 


\section{Carbon mineralization}

The cumulative $\mathrm{C}$ mineralization from roots, expressed as the proportion of added $\mathrm{C}$, varied widely among the treatments, both in terms of kinetics and of total $\mathrm{C}$ mineralized at day 120 (Fig. 2a; Table 3).

Table 3: Root $\mathrm{C}$ mineralization measured and potentially mineralizable $\mathrm{C}$ pool and mineralization constant calculated using a simple exponential equation, for twenty species incubated at $25^{\circ} \mathrm{C}$ during 120 days.

\begin{tabular}{|c|c|c|c|c|}
\hline Plant (REF) & $\begin{array}{c}\mathrm{C} \min ^{\mathrm{a}} \\
\%\end{array}$ & $\begin{array}{l}C_{0}^{\mathrm{b}} \\
\%\end{array}$ & $\begin{array}{c}k^{\mathrm{c}} \\
\text { day }^{-1}\end{array}$ & $R^{2 \mathrm{~d}}$ \\
\hline Sunflower (4) & 59.3a\# & 58.7 & 0.038 & 0.99 \\
\hline Oilseed radish (14) & $39.4 \mathrm{c}$ & 38.3 & 0.086 & 0.99 \\
\hline Oilseed rape (18) & $52.7 \mathrm{~b}$ & 50.1 & 0.062 & 0.99 \\
\hline Bean (1) & $58.2 \mathrm{a}$ & 54.9 & 0.052 & 0.99 \\
\hline Soybean (2) & $39.2 \mathrm{c}$ & 37.2 & 0.059 & 0.99 \\
\hline Sunn hemp (5) & $53.1 \mathrm{~b}$ & 50.9 & 0.038 & 0.99 \\
\hline Jack bean (6) & $56.9 \mathrm{a}$ & 53.7 & 0.071 & 0.99 \\
\hline Gray mucuna (7) & $42.3 \mathrm{c}$ & 40.0 & 0.099 & 0.98 \\
\hline Showy rattlebox (10) & $38.3 \mathrm{c}$ & 37.8 & 0.055 & 0.99 \\
\hline Vetch (12) & $43.1 \mathrm{c}$ & 39.5 & 0.134 & 0.99 \\
\hline Pea (16) & $44.0 \mathrm{c}$ & 40.7 & 0.109 & 0.98 \\
\hline Maize (3) & $43.9 \mathrm{c}$ & 41.3 & 0.057 & 0.99 \\
\hline Millet (8) & $40.3 \mathrm{c}$ & 41.9 & 0.024 & 0.99 \\
\hline Sorghum (9) & $48.5 \mathrm{~b}$ & 44.0 & 0.051 & 0.94 \\
\hline Black oat (11) & $44.4 \mathrm{c}$ & 44.7 & 0.027 & 0.99 \\
\hline Wheat (13) & $40.5 \mathrm{c}$ & 38.8 & 0.033 & 0.98 \\
\hline Rye (15) & $40.6 \mathrm{c}$ & 38.3 & 0.046 & 0.97 \\
\hline Triticale (17) & $41.6 \mathrm{c}$ & 39.3 & 0.041 & 0.95 \\
\hline Barley (19) & $35.8 \mathrm{c}$ & 33.8 & 0.065 & 0.97 \\
\hline Ryegrass (20) & $43.0 \mathrm{c}$ & 42.3 & 0.041 & 0.99 \\
\hline \multicolumn{5}{|c|}{$\begin{array}{l}{ }^{\mathrm{a}} \text { The } \% \text { of added } \mathrm{C} \text { mineralized measured from } \\
\text { roots after } 120 \text { days. } \\
{ }^{\mathrm{b}} \text { Potentially mineralizable } \mathrm{C} \text { pool. } \\
{ }^{\mathrm{c}} \text { Mineralization constant rate. } \\
{ }^{\mathrm{d}} \text { Coefficient of determination between measured } \\
\text { and predicted values. } \\
{ }^{*} \text { Values with different letters are different by } \\
\text { Scott-Knott test }(P<0.05) \text {. }\end{array}$} \\
\hline
\end{tabular}

At the end of the incubation period (120 days), the cumulative $\mathrm{C}$ mineralized varied from $36 \pm 2.5 \%$ added $C$ (barley, number 19) to $59 \pm 3.5 \%$ added $\mathrm{C}$ (sunflower, number 4 ). The species can be grouped into three groups based on statistical differences in the amounts of cumulative $\mathrm{C}$ mineralized measured during 120 days. In the first and second groups, with three species each, mineralized $\mathrm{C}$ ranged from 56.9 to $59.3 \%$ added $\mathrm{C}$ and $48.5 \%$ to $53.1 \%$ added $\mathrm{C}$, respectively; in the third group, 14 species showed mineralized $\mathrm{C}$ values ranging from 35.8 to $44.4 \%$ added C. However the kinetics of mineralization showed strong differences between species as shown, as example, with species 1, 10, 12 and 19 (Fig. $2 b)$. The roots of species 10,12 and 19 had no significant differences in their total $\mathrm{C}$ mineralized, but had very different kinetics of mineralization.
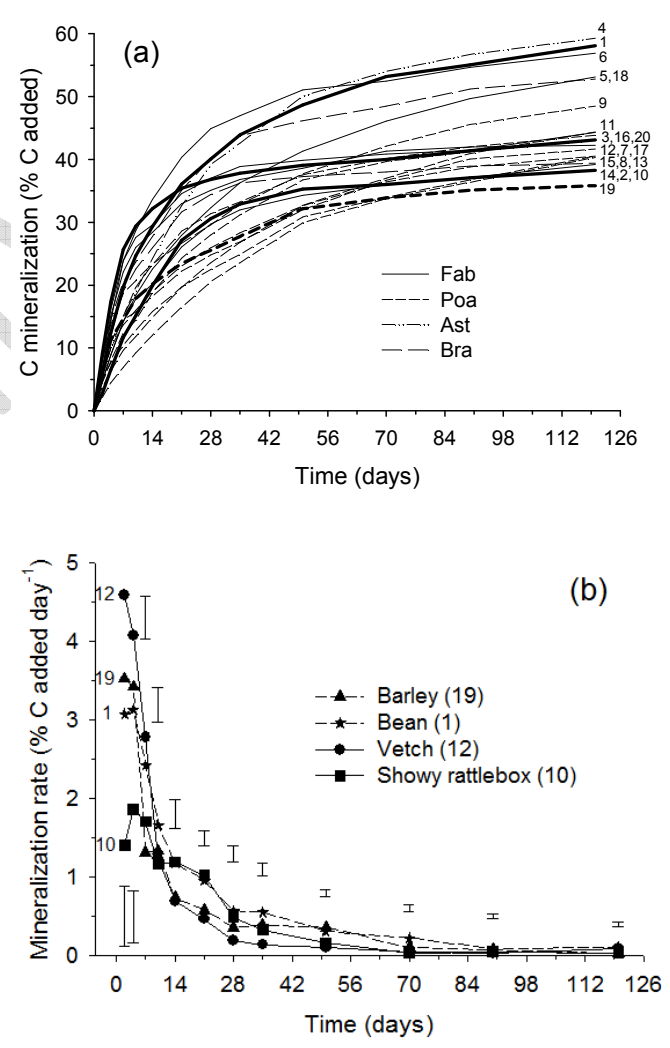

Fig. 2: Cumulative $\mathrm{C}$ mineralization of roots of 20 species during incubation in soil during 120 days at $25^{\circ} \mathrm{C}$ (a) and rates of $\mathrm{C}$ mineralization during decomposition for 4 species among the 20 species studied (b). These 4 species are three Fabaceae crops (vetch, 12; bean, 1; showy rattlebox, 10) and 1 Poaceae crop (barley, 19). The data plotted are the means $(n=3)$. The vertical bars indicate the minimum significant difference between the treatments (Tukey's test, $P<0.05$ ). Fab: Fabaceae; Poa: 
Poaceae; Ast: Asteraceae; Bra: Brassicaceae. The identification numbers of the 20 species studied are provided in Table 1.

In general the roots of the Fabaceae species plants exhibited higher levels of cumulative $\mathrm{C}$ mineralization (ranging from $38 \%$ for showy rattlebox to $58 \%$ for bean) than the roots of Poaceae species plants (ranging from $36 \%$ for barley to $49 \%$ for sorghum). The roots of the single Asteraceae species studied (sunflower, number 4) exhibited the highest cumulative C mineralization (59\%), whereas the two Brassicaceae species (numbers 14 and 18) were in the low and high range (39 and $53 \%$, respectively).

The potentially mineralizable $\mathrm{C}$ pool $\left(C_{0}\right)$ calculated with a simple exponential decay function using the cumulative $\mathrm{C}$ mineralized (Fig. 2a) ranged from 33.8 to $58.7 \%$ added $\mathrm{C}$ and was close to the measured cumulative $\mathrm{C}$ mineralized during 120 days (Table 3 ). The mineralization constant $(k)$ of the $C_{0}$ differed among roots (Table 3 ) and ranged from 0.024 for millet root (8) to 0.134 for vetch root (12).

Relationships between the root chemical composition and $\mathrm{C}$ mineralization

The relationships between the decomposition constants of C mineralized ( $k$; Table 3) and the initial root chemical composition, using all chemical characteristics and analyzed by stepwise regression with standardized coefficients was $k=-0.29 \mathrm{HEM}+$ $0.74 \mathrm{~N}, r^{2}=0.74, P<0.001$. The regression using only data from proximate analysis (SOL, HEM, CEL and LIG) was $k=-0.75$ HEM $0.75 \mathrm{CEL}, r^{2}=0.72, P<0.001$. For $C_{0}$, the corresponding equations were $C_{0}=0.72 \mathrm{CEL}+$ $0.54 \mathrm{Csw}, r^{2}=0.56, P<0.001$ (all chemical data) and $C_{0}=0.55$ CEL $, \quad r^{2}=0.30, \quad P<0.001$ (proximate analysis). Using the PCA approach, the mineralization constant $(k)$ was positively correlated with POL, SOL, $\mathrm{N}$ and soluble fractions (Fig. 1b), and negatively correlated with CEL and HEM. The potential mineralization pool $\left(C_{0}\right)$ was positively correlated CEL and LIG, and negatively correlated with HEM.

\section{Discussion}

Chemical composition of roots

Many plants used in crop rotations differ widely with regard to the chemical composition of their tissues (Abiven et al. 2005; Silver and Miya 2001), and the roots of these plants may contribute differently to soil C inputs (Rasse et al. 2005; Johnson et al. 2007; Kong and Six 2010). The results of the present study confirmed our hypothesis that there is a large variation in the root biochemical composition among plant species grown under similar conditions, which can be partly explained by the fact that the plants belong to different botanical families. Indeed, this has also been clearly shown with plant species from natural ecosystems, and identified as interspecific variations in functional traits (Roumet et al. 2008; Aulen et al. 2012; PiconCochard et al. 2012). The roots of the Fabaceae (legumes), Asteraceae, and Brassicaceae families, which are all in the dicotyledons, were characterized by large variations in composition among species and by their higher, on average, CEL and LIG fractions compared to Poaceae roots. Conversely, the proportion of HEM in the roots of Poaceae family was higher than for other species, and the differences in composition among Poaceae species were lower. These differences reflect the different types of root systems with a greater proportion of coarse roots with Fabaceae and Brassicaceae species compared to Poaceae species, which implies a relatively higher amount of plant cell wall material. Although maize, millet, and sorghum also have coarse roots, their LIG contents were found to be in the range of other Poaceae species, suggesting that taxonomical affiliation prevails over root morphology. Roumet et al. (2008) reported that the root tissues of Fabaceae 
species are characterized by higher total $\mathrm{N}$ than those of Poaceae species, which is consistent with our results; based on their study of a range of functional traits of roots, these authors concluded that Poaceae and Fabaceae differ for the entire set of traits examined. However the interspecific variation did not explain all differences, and it is noticeable that within the Fabaceae family, pea (16) vetch (12) and gray mucuna (7) strongly differed from other species without any identified explanation associated to crop management.

The average LIG content of the roots of the 20 species of plants considered in the present study (119 $\mathrm{g} \mathrm{LIG} \mathrm{kg}^{-1} \mathrm{DM}$ ) was lower than the values reported in most published studies, such as that of Abiven et al. (2005), who reported values in the range of 160 to 260 g LIG $\mathrm{kg}^{-1} \mathrm{DM}$. Using a global dataset, Silver and Miya (2001) also measured high LIG contents in the roots of graminoid (Poaceae), broadleaf, and conifer (180 to $270 \mathrm{~g} \mathrm{LIG} \mathrm{kg}^{-1}$ DM). In contrast, Lindedam et al. (2009) measured lower LIG contents in grass and clover roots $\left(110 \mathrm{~g} \mathrm{~kg}^{-1}\right)$, consistent with our results. The relatively low LIG content of the roots used in our study might be explained by the fact that they were collected at the flowering stage. Bertrand et al. (2009) showed that the content of the cell wall material of wheat internodes increased by $85 \%$ from the flowering stage to physiological maturity, and Abiven et al. (2011) observed that the LIG contents of maize and wheat roots increased substantially between the flowering and maturity stages, with a larger increase in maize roots (i.e., by a factor of 3.3). In addition, Picon-Cochard et al. (2012) observed that the LIG contents of the roots of 13 grass species varied over the growing season. Indeed, change in the chemical composition of roots with the season or plant development stage is an important factor to consider when comparing families or species of plants or using data from the literature. These findings suggest that our data may represent the quality of the root system of annual crops at a time at which root turnover is often considered to begin (Rasse et al. 2005) but most likely underestimate the lignin content of the roots at crop maturity. However, a comparison of our data and that from the literature cited above, showed that the pattern observed for the chemical quality of the roots as a function of plant species and botanical family was consistent.

Effect of chemical composition on $\mathrm{C}$ mineralization

Both the cumulative $\mathrm{C}$ mineralization after 120 days of incubation and the kinetics of $\mathrm{C}$ mineralization varied greatly among the species. The range of cumulative $\mathrm{C}$ mineralization of the root C (from 36 to $59 \%$ of added $\mathrm{C}$ ) and the differences between Fabaceae and Poaceae species were consistent with the observations in other studies conducted under similar experimental conditions (Trinsoutrot et al. 2000; De Neergaard et al. 2002; Abiven et al. 2005). De Neergaard et al. (2002) also detected a large difference in the cumulative $\mathrm{C}$ mineralization between white clover roots (Fabaceae) and perennial ryegrass roots (Poaceae), with the clover roots mineralizing approximately $50 \%$ more $\mathrm{C}$ than ryegrass after 94 days of incubation. Lindedam et al. (2009) observed that the extent of decomposition of clover roots was double that of fescue grass roots after 118 days of incubation.

We assessed prediction of root mineralization as a function of chemical quality by different ways either related to the size of the $\mathrm{C}$ pool mineralized (measured and modeled) or to the rates of mineralization (measured and modeled). The roots showed mineralization kinetics very different, but ultimately they are classified in only three statistically different groups, according to their cumulative total mineralization at day 120 . The correlations shown with PCA analysis, indicated that total $\mathrm{N}$, total soluble polyphenols and soluble fractions (Van Soest, water soluble 
$\mathrm{N}$ and $\mathrm{C}$ ) were correlated with $k$. The analysis made with multiple regression indicated that the best plant characteristics to predict $k$ were hemicelluloses and total $\mathrm{N}$ concentrations. As discussed by Aulen et al. (2012), the effect of $\mathrm{N}$ on litter decomposition rate is controversial. Two factors are involved into the N-controlled mechanisms: the intrinsic tissue $\mathrm{N}$ content and the extrinsic soil inorganic $\mathrm{N}$ nutrient availability which may control decomposition when overall $\mathrm{N}$ availability is limiting decomposers activity. In our study, we added inorganic $\mathrm{N}$ in soil prior to the incubation, to avoid a potential limitation of decomposition by the availability of soil $\mathrm{N}$ and to univocally examine the effects of the plant tissues composition. The results suggest that the available root $\mathrm{N}$ (total soluble organic and inorganic $\mathrm{N}$ represented, on average, $47 \%$ and $7 \%$ of the total $\mathrm{N}$, respectively in roots) favored the fast decomposition, particularly for root residues which also had high soluble $\mathrm{C}$ content. Conversely, polyphenols content was not relevant to predict mineralization. Indeed high polyphenols content was associated to high $\mathrm{N}$ content in the Fabaceae roots, as expected in leguminous plants (Constantinides and Fownes, 1994).

Plant residues consist of a soluble and insoluble fractions (cell wall). Cell walls consist mainly of insoluble polymers such as cellulose, hemicelluloses and lignin, which form a complex, chemical network that influences biological degradation (Chesson 1988; Bertrand et al. 2006). Our results did not show that lignin content was relevant for predicting the mineralization constant $(k)$ and the mineralizable $\mathrm{C}$ pool $\left(C_{0}\right)$. Indeed lignin control of decomposition rates is not always confirmed. Silver and Miya (2001) looking at global pattern of root decomposition, also found that lignin explained only small proportion of the pattern observed. In the work of Trinsoutrot et al. (2000) with mineralization data from 47 different crop residues, lignin content did not appear as a predictor of the mineralization constant $k$. Jensen et al. (2005) using 249 different above-ground residues from crops, found that holocellulose (hemicelluloses + cellulose) was the single factor that explain the variability of $\mathrm{C}$ mineralization. Recently, finer scale residue chemical characteristics related to hemicellulose substitution level (i.e., arabinose to xylose ratio), and interactions between cellulose, hemicellulose and lignin have provided new insights to chemical controls on decomposition (Machinet et al. 2009, 2011). These studies demonstrated that $\mathrm{C}$ mineralization of maize roots in soil was described by both cell wall polymer content, cross linking agents (phenolic acids) between hemicellulose and lignin, and the substitution level of hemicelluloses. Our results with a large database with roots of annual plants, confirm the central role of hemicellulose and cellulose in the ability of roots to biodegradation.

Several studies have shown that the contribution of roots to soil organic $\mathrm{C}$ is 2.4 (Rasse et al. 2005) to 13 times higher than the contribution of shoots (Kong and Six 2010). According to Aulen et al. (2012), the decomposition of fine roots involves constant and intimate interaction at a very fine spatial scale between roots and their surrounding rhizosphere. The fact that the Poaceae species (Gramineae) plants considered in this study had higher proportions of fine roots and the lowest levels of cumulative mineralized $\mathrm{C}$ suggests that fine roots of graminae could make an important contribution to $\mathrm{C}$ storage in soil. A few other crop species from the Fabaceae family, used in this study, had similar characteristics. Therefore, the appropriate management of crop rotation with species belonging to Poaceae and Fabaceae, intercropped with cover crops, may represent an important mechanism for the combined stabilization of $\mathrm{C}$ in soil and the recycling of nutrients for crops. 


\section{Acknowledgments}

This work was supported by the Brazilian government through the Conselho Nacional de Desenvolvimento Científico e Tecnológico (CNPq). The bilateral Brazilian and French collaboration was funded under the Program $\mathrm{CNPq}$ - Ciência sem Fronteiras (Process Number 401724/2012-3) -and by the INRA (the Environment \& Agronomy Division) during M. Redin's residence at UMR FARE in Reims, France. The authors thank anonymous referees for their constructive comments on the previous version of this work.

\section{References}

Abiven S, Recous S, Reyes V, Oliver R (2005) Mineralisation of $\mathrm{C}$ and $\mathrm{N}$ from root, stem and leaf residues in soil and role of their biochemical quality. Biol Fertil Soils 42:119128

Abiven S, Heim A, Schmidt MWI (2011) Lignin content and chemical characteristics in maize and wheat vary between plant organs and growth stages: consequences for assessing lignin dynamics in soil. Plant Soil 343:369378

Amos B, Walters DT (2006) Maize root biomass and net rhizodeposited carbon: An analysis of the literature. Soil Sci Soc Am J 70:1489-1503

Aulen M, Shipley B, Bradley R (2012) Prediction of in situ root decomposition rates in an interspecific context from chemical and morphological traits. Ann Bot 109:287-297

Bertrand I, Chabbert B, Kurek B, Recous $S$ (2006) Can the biochemical features and histology of wheat residues explain their decomposition in soil? Plant Soil 281:291-307

Bertrand I, Prevot M, Brigitte C (2009) Soil decomposition of wheat internodes of different maturity stages: Relative impact of the soluble and structural fractions. Bioresour Technol 100:155-163

Birouste M, Kazakou E, Blanchard A, Roumet C (2012) Plant traits and decomposition: are the relationships for roots comparable to those for leaves? Ann Bot 109: 463-472

Carrera AL, Bertiller MB, Larreguy C (2008) Leaf litterfall, fine-root production, and decomposition in shrublands with different canopy structure induced by grazing in the Patagonian Monte, Argentina. Plant Soil 311:39-50

Chesson A (1988) Lignin-polysaccharide complexes of the plant cell wall and their effect on microbial degradation in the rumen. Anim Feed Sci Technol 21:219-228

Constantinides M, Fownes JH (1994) Nitrogen mineralization dynamics of soil mineral $\mathrm{N}$ from leaves and litter of tropical plants: Relationship to nitrogen, lignin and soluble polyphenol concentrations. Soil Biol Biochem 26:49-55

De Neergaard A, Hauggaard-Nielsen H, Jensen LS, Magid J (2002) Decomposition of white clover (Trifolium repens) and ryegrass (Lolium perenne) components: $\mathrm{C}$ and $\mathrm{N}$ dynamics simulated with the DAISY soil organic matter submodel. Eur J Agron 16:4355

Guénon R, Vennetier M, Pailler A, Dupuy N, Roussos S, Gros R (2013) Trends in recovery of Mediterranean soil chemical properties and microbial activities after infrequent and frequent wildfires. Land Degrad Dev 24:115-128

Heal OW, Anderson JM, Swift MJ (1997) Plant litter quality and decomposition: an historical overview. In: Cadish G, Giller KE (eds) Driven by nature: plant litter quality and decomposition. $\mathrm{CAB}$ International, Wallingford, pp 3-30

Jensen LS, Salo T, Palmason F, Breland TA, Henriksen TM, Stenberg B, Pedersen A, Lundström C, Esala M (2005) Influence of biochemical quality on $\mathrm{C}$ and $\mathrm{N}$ mineralisation from a broad variety of plant materials in soil. Plant Soil 273:307-326

Johnson JMF, Barbour NW, Weyers SL (2007) Chemical composition of crop biomass impacts its decomposition. Soil Sci Soc Am J 71: $155-162$ 
Jung JY, Lal R, Ussiri DAN (2011) Changes in $\mathrm{CO}_{2},{ }^{13} \mathrm{C}$ abundance, inorganic nitrogen, $\beta$-glucosidase, and oxidative enzyme activities of soil during the decomposition of switchgrass root carbon as affected by inorganic nitrogen additions. Biol Fertil Soils 47:801-813

King HG, Health GW (1967) The chemical analyses of small samples of leaf material and the relationship between the disappearance and composition of leaves. Pedobiologia 7:192-197

Kong AYY, Six J (2010) Tracing cover crop root versus residue carbon into soils from conventional, low-input, and organic cropping systems. Soil Sci Soc Am J 74:1201-1210

Lindedam J, Magid J, Poulsen P, Luxhøi J (2009) Tissue architecture and soil fertility controls on decomposer communities and decomposition of roots. Soil Biol Biochem 41:1040-1049

Machinet GE, Bertrand I, Chabbert B, Watteau F, Villemin G, Recous S (2009) Soil biodegradation of maize root residues: Interaction between chemical characteristics and the presence of colonizing microorganisms. Soil Biol Biochem 41:1253-1261

Machinet GE, Bertrand I, Barrière Y, Chabbert B, Recous S (2011) Impact of plant cell wall network on biodegradation in soil: Role of lignin composition and phenolic acids in roots from 16 maize genotypes. Soil Biol Biochem 43, 7, 1544-1552

Picon-Cochard C, Pilon R, Tarroux E, Pagès L, Robertson J, Dawson L, (2012) Effect of species, root branching order and season on the root traits of 13 perennial grass species. Plant Soil 353:47-57

Rasse DP, Rumpel C, Dignac MF (2005) Is soil carbon mostly root carbon? Mechanisms for a specific stabilisation. Plant Soil 269:341356

Recous S, Robin D, Darwis D, Mary B (1995) Soil inorganic N availability: Effect on maize residue decomposition. Soil Biol Biochem 27:1529-1538
Roumet C, Lafont F, Sari M, Warembourg F, Garnier E (2008) Root traits and taxonomic affiliation of nine herbaceous species grown in glasshouse conditions. Plant Soil 312:69-83

Silver WL, Miya RK (2001) Global patterns in root decomposition: comparisons of climate and litter quality effects. Oecologia 129:407-419

Tian G, Brussaard L, Kang BT (1995) An index for assessing the quality of plant residues and evaluating their effects on soil and crop in the sub-humid tropics. Appl Soil Ecol 2:25-32

Trinsoutrot I, Recous $\mathrm{S}$, Bentz $\mathrm{B}$, Linères $M$, Chèneby $D$, Nicolardot $B$ (2000a) Biochemical quality of crop residues and carbon and nitrogen mineralization kinetics under nonlimiting nitrogen conditions. Soil Sci Soc Am J 64:918-926

Van Soest PJ (1963) Use of detergents in the analysis of fibrous feeds I: preparation of fiber residues of low nitrogen content. J Assoc Off Ana Chem 46:825-835

Zhang D, Hui D, Luo Y, Zhou G (2008) Rates of litter decomposition in terrestrial ecosystems: global patterns and controlling factors. J Plant Ecol 1:85-93 